\title{
Breadwaste as a Dietary Supplement for Maize in the Practical Diets of African Giant Catfish (Clarias Gariepinus, Burchell 1822) Fingerlings.
}

\author{
Fakunmoju F.A. \\ Department Of Fisheries Technology, Lagos State Polytechnic, Ikorodu-Lagos, Nigeria
}

\begin{abstract}
Experiment was conducted to evaluate the growth performance of African giant catfish (Clarias gariepinus) fed varying levels of bread waste based diets. Three hundred (300) clarias gariepinus fingerlings with mean body weight of $5.2 \pm 0.1 \mathrm{~g}$ were assigned to five diets $(c . p=42 \%)$ in which bread waste meal replaced maize at $0,25,50,75,100 \%$ respectively in a completely randomized design replicated 3 times. The trial fish were fed at 5\% body weight daily for a period of 24 days. Data collected showed that body weight gain increased with increase bread waste meal in the diet $(p<0.05)$. Similar observation was recorded for feed intake but there was no significant $(p>0.05)$ difference in feed conversion ratio among the treatments. All the fish fed the test ingredients performed better than the control group; hence, bread waste meal could be recommended as a dietary supplement in the diets of African giant catfish.

Keywords: Bread waste meal, Clarias gariepinus, supplement, growth performance, diets.
\end{abstract}

\section{Introduction}

The animal protein intake of average Nigerian is low compared to other developed nations of the world FAO (1992). In order to increase the animal protein intake, there is need for expansion of livestock industry which is the main source of the protein. One of the challenges facing livestock industry in Nigeria is high cost of feed which has led to closure of some farms. The use of agro - industrial by-products(AIBS) has been one of the panacea to high feed cost, several authors have used different (AIB) such as pineapple waste, Bambara groundnut, poultry waste (chicken offal, rice bran, castor oil bean, kolanut husk, rumen content, blood rumen, sunflower seed cake, shrimp waste meal, etc. Ademiji C.A. (2005): Ani A.O and A.V. Okorie (2005); Dairo et al (2005); Babatunde, et al (2001); Hamzat et al (2004). Bread waste, a by product of bakery industry is rich in energy, low in fibre but high in vitamins has been used to replace maize in the diet of broiler, Abdulatif, et al (2004); Dabron et al (1999), which has led to reduction in feed cost. Bread waste is cheap and available in bakery industry in Nigeria. There is paucity of information on the use of bread waste in the diet of snails hence this study was conducted to determine the performance and effect of replacing maize fraction of the diet of clarias gariepinus fingerlings with bread waste.

\section{Experimental site and sample preparation}

\section{Materials And Methods}

The experiment was conducted at the Department of fisheries technology lagos state polytechnic Ikorodu, lagos state. The sample (Bread waste \} were collected from UAC foods limited, lagos.

They were sun dried for two weeks, grind and sieved to produce bread waste meal. Sample of the meal was analysed for proximate composition (Table 2).

\section{Feed formulation}

The meal produced (bread waste) was mixed with other feeding ingredients to formulate five isonitrogeneous diets at $43 \%$ crude protein in which bread waste meal was to replace maize at $0 \%, 25 \%, 50 \%, 75 \%$ and $100 \%$ respectively, while the control diet $(0 \%)$ contained no bread waste meal. The diets produced were passed through a pelleting machine of die $2 \mathrm{~mm}$ to produce pellets. Thereafter, the pelleted feeds were sun dried to crispy for four (4) days to prevent the growth of moulds and were packed in water proof bags and labelled accordingly before storage at room temperature. These were later analysed using the A.O.A.C Official method of analysis (1995).

\section{Experimental fish and design}

Three hundred (300) catfish fingerlings with an average of 5.2g body weight were purchased from a commercial hatchery in Ikorodu lagos state. They were acclimatized for seven (7) days and fed with control diet $(0 \%)$ subsequently, they were randomly assigned to the five treatment diet at 60 fish per treatment in hapa measuring 1.1 by $0.9 \mathrm{~m}$ suspended in outdoor concrete tank measuring $3.3 \times 3.3 \mathrm{~m}$. Each treatment is replicated 
trice in a completely randomized design having twenty (20) fish per replicate. They were fed the experimental diet for a period of 12 weeks at the rate of $5 \%$ body weight per day, showed between morning (7-8am) and evening (5-6pm). The water was changed every other day to allow for good performance of the fish.

\section{Data collection and statistical analysis}

The experimental fish (fingerlings) in each hapa were weighed at the beginning of the experiment and forth nightly, using a digital weighing balance and returned into the respective hapas thereafter, their feed intake were adjusted according to the new body weight gained forth nightly.

Data on feed intake, weight gained and fed conversion ratio for the five groups were collected and subjected to analysis of variance, where significant differences was detected, means were separated using multiple range test as outlined by obi (1990).

Table 1. Gross composition of experimental diet

\begin{tabular}{|c|c|c|c|c|c|}
\hline Ingredients & BW0\% & BW25\% & BW50\% & BW75\% & $\%$ BW $100 \%$ \\
\hline Maize & 30 & 22.5 & 15 & 7.5 & - \\
\hline Bread waste & - & 7.5 & 15 & 22.5 & 30 \\
\hline Fishmeal & 45 & 45 & 45 & 45 & 45 \\
\hline Soyameal & 17.25 & 17.25 & 17.25 & 17.25 & 17.25 \\
\hline Bone meal & 5 & 5 & 5 & 5 & 5 \\
\hline Fish premix & 0.25 & 0.25 & 0.25 & 0.25 & 0.25 \\
\hline Salt & 0.25 & 0.25 & 0.25 & 0.25 & 0.25 \\
\hline Vit C & 0.25 & 0.25 & 0.25 & 0.25 & 0.25 \\
\hline Starch Binder & r 1.00 & 1.00 & 1.00 & 1.00 & 1.00 \\
\hline Lysine & 0.5 & 0.5 & 0.5 & 0.5 & 0.5 \\
\hline Methionine & 0.5 & 0.5 & 0.5 & 0.5 & 0.5 \\
\hline \multicolumn{6}{|c|}{ Calculated analysis } \\
\hline $\begin{array}{l}\text { Crude protein } \\
\text { Metabolizable }\end{array}$ & $e^{43 \%}$ & $43.14 \%$ & $43.38 \%$ & $43.57 \%$ & $6 \quad 43.77 \%$ \\
\hline Energy(Kcal/ & $1 / \mathrm{kg} \mathrm{ME}$ & 736.9 & 5.292 & 53.68 & $62.07 \quad 277$ \\
\hline
\end{tabular}

\section{Result And Discussion}

The chemical composition of the bread waste showed that the crude protein of bread waste (BW) was nearly the same with that of maize while the crude fibre of BW was lower than that of maize (Table 2). The crude protein for BW in this report was recently similar to $10.00 \%$ reported by Abdulatif et al (2004). The chemical composition of the experimental diets revealed that the crude protein and crude fibre content of the feed were within the recommended values as reported by Fagbenro and Arowosoge (1991).

However, the crude protein content of the diets increased with increased dietary inclusion of bread waste meal (table 2). This is attributed to superior crude protein content of the test ingredient used over maize (table 2).

The weight gain and specific growth rate of the fish fed bread waste meal based diets were superior to the control group $(\mathrm{p}<0.05)$. It should be noted that cultured fish in concrete ponds and other artificial enclosures depends solely on the nutrient from the feed for growth with little or no contribution from natural food, hence, the general increase in weight of the trial fish was an indication that all the diets met the nutrient requirement for growth in African giant catfish particularly the crude protein $(\mathrm{cp}=43 \%)$ and perhaps the protein energy ratio Fagbenro and Arowosoge (1991); Agbabiaka (2010b).

All the bread waste meal diets supported growth more than the control perhaps due to the medium where fish lives which might have encouraged the growth of phytoplanktons.

The improve weight gain in bread waste meal treatment can also be due to the fibre content of the diets being lower than that of the control diet (table 2). Though all the dietary treatments have fibre concentrations within the recommended range of $8 \%$ for catfish. Davis (1985) 
Table 2: Determined proximate composition of the maize ,bread waste and experimental diets

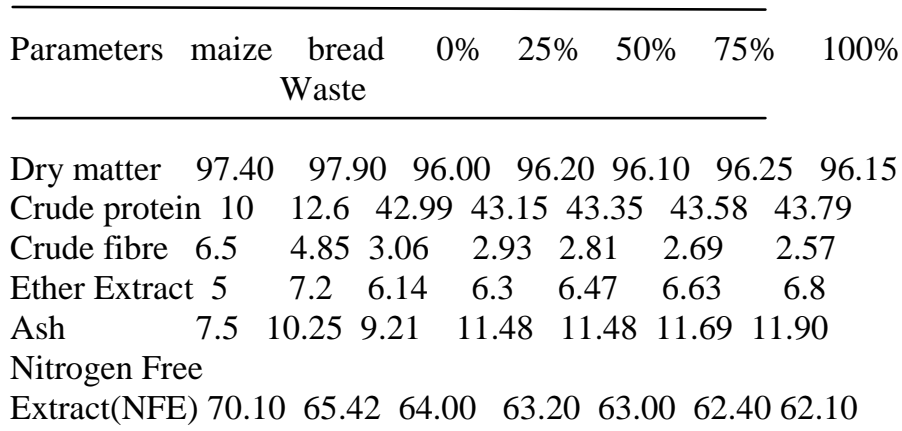

Table 3: Performance characteristics of fish fed different levels of Dietary bread waste meal $(0-12)$ wks

\begin{tabular}{|c|c|c|c|c|c|}
\hline \multirow{2}{*}{-Parameter } & \multicolumn{5}{|c|}{ Treatment $\operatorname{diets}(\%)$} \\
\hline & $\mathbf{0}$ & 25 & 50 & 75 & 100 \\
\hline Initial weight(g) & 5.2 & 5.2 & 5.2 & 5.2 & 5.2 \\
\hline Final weight(g) & 134.58 & 135.76 & 135.90 & 136.10 & 136.9 \\
\hline Weight gain $(g) \quad 1$ & $129.38 b \quad 1$ & $130.56 b$ & $130.7 b$ & $130.9 \mathrm{a}$ & $131.7 \mathrm{a}$ \\
\hline Total feed intake & (g) $41.8 \mathrm{~b}$ & $46.6 b$ & $74.6 \mathrm{a}$ & $83.6 \mathrm{a}$ & $86.6 a$ \\
\hline Mean growth rate & (g) 1.54 & 1.55 & 1.56 & 1.56 & 1.57 \\
\hline Feed conversion $r$ & ratio 0.32 & $2 \mathrm{a} \quad 0.36 \mathrm{a}$ & a $\quad 0.57 \mathrm{a}$ & $\mathrm{ab} \quad 0.64 \mathrm{~b}$ & $0.66 \mathrm{~b}$ \\
\hline Mortality rate & 2.00 & 0.40 & 0.20 & 0.00 & 0.00 \\
\hline
\end{tabular}

ab means with same superscript within rows are not significantly ( $>>0.05)$ different.

Bright S.O (1996) and Kehinde A.J (2009) reported better utilization of cassava peels by African giant snail, which was in agreement with the findings of Omole et al (2004) when snails were fed bread waste meal.

The feed intake of the trial fish is directly proportional to the dietary level of the bread waste meal. It has been reported that feed intake of the monogastrics including fishes is a function of the dietary energy, that is animals will continue to eat until the energy requirement is met Esonu (2000).

It could be observed also that all the diets containing bread waste meal were lower in concentration of Nitrogen free extract, lipid and crude fibre which are main source of dietary energy, relative to the control(maize) diet. This might have been a major significant factor responsible for higher feed intake by the fish fed the test diets (table 3). This is in agreement with the finding of Vantsawa et al (2008) that energy content of feed/diet is inversely proportional to the feed intake, which was also observed when maize offals was fed to laying chickens. The overall low mortality recorded from this study showed that the physiochemical parameters of the pond water was not adversely affected by the bread waste meal and are within the recommended ranges for catfish fingerlings Boyd (1979).

\section{Conclusion}

This study has shown that bread waste meal diet can be utilized by African giant catfish, hence, can replace the more expensive maize, thereby, reducing the cost of production and control environmental filth associated with bread waste in Nigeria. The best conversion ratio was reported in the control group $(0 \%)$ with the value of 0.32 whil the poorest value of 0.66 was obtained from fish fed $100 \%$ bread waste diet. There was no significant difference $(\mathrm{p}>0.05)$ among the treatment group.

\section{Reference}

[1]. Abdulatif. A, Salah. M , AL- Tulaihna, Hutail. A (2004). Nutritional Evaluation of dried Bakery ProductPakistan Journal of Nutrition 3(5) 294 - 299.

[2]. Ademiji .C.A. (2005). Performance and Carcass characteristics of broiler Chicken fed high fibre sunflower Seed cake diet. Nigeria Journal of Animal production.

[3]. Agbabiaka L.A (2010b): Evaluation of Some underutilized protein feedstuff In diets of clarias gariepinus finger-Lings. International Journal of Tropical Agric and Food system 4(1): $10-12$.

[4]. Ani, A.O and A.V.Okorie (2005): The Effect of graded levels of dehulled and cooked castor oil bean meal on performance of broiler starters. Nigeria Journal of Animal production 32: 5460

[5]. A.O.A.C (1995): Association of official Analytical Chemist, Official Method of Analysis (16 $\left.{ }^{\mathrm{TM}} \mathrm{ed}\right)$. Holder and Stoughton London .pp. $16-18$.

[6]. Babatunde B.B, R.A. Hamzat and O.O Ademiji (2001): Replacement value of kolanut husk meal for maize in rabbit diets. Tropical Journal of Animal Science $4 \quad$ (2) $127-133$

[7]. Boyd C.E (1979). Water quality in warm water fish ponds. Auburn University Alabama Agric Experimental Station 359pp. 
[8]. Bright, S.O. (1996): Prospects and Problem Associated with snail farming. Heritage Practices Nig Ltd Lagos. 96pp

[9]. Dabron B.L, Waidroup, P.N. Hams, R.H (1999): The metabolizable energy of dried bakery product for use in broiler diet Poultry Science 69:72-75

[10]. Dairo F,A.S, O.O Aina and A.R. Asafa(2005); Performance evaluation of growing rabbits fed varying levels of rumen content and blood rumen content mixture. Nigeria Journal of Animal Production 32:67-73

[11]. Davis S.J(1985): The role of dietary fibre in fish nutrition. In: proceeding of recent advances in aquaculture Muir,J.F. and.Roberts, R,J (eds) croom Helm. London. 219-238

[12]. Esonu B.O (200): Animal Nutrition and feeding: A functional Approach. Rukzad and Rucksons Associates, Owerri.

[13]. Fagbenro O.A and Arowosoge . A.J (1991): Growth response and nutrient digestibility of clarias isheriensis sydenham1980) fed varying levels of low cost diets. Bio res(ource Technology 37. 253-258.

[14]. FAO (1992): Production year book, 1992, volume 36, FAO, Rome,Italy.

[15]. Hamzat, R.A and B.B. Babatunde(2004): Performance characteristics of broiler finisher fed kola pod husk based diet Moor Journal of Agric .Research 2.153- 158

[16]. Kehinde A.J (2009): Utilization of cassava peel products in the life cycle feeding of snail (Archatina marginata). Phd Thesis, Department of Animal Science,University of Ibadan (unpublished)

[17]. Obi I.U (1990): Statistical methods of detecting differences between treatment means. $2^{\text {nd }}$ edition. Snaap press, Enugu, Nigeria

[18]. Omole A.J, Ayodeji I.O and Raji M.A (2004): The potential of peels of mango, plantain, cocoyam and pawpaw as diets growing snail (Archantina marginata) . Livestock Research for Rural Development 16 (12): 1-5

[19]. Vantsawa P.A, Ogundipe S.O. Dafwango I.I and Omage J.J (2008): Replacement value of Dusa (locally processed maize offal) for maize in diets of pullets and subsequent early laying characteristics.Pakistan Journal of Nutrition, 7(4): $574-577$. 